\title{
Sylwia Machowska-Okrój
}

Uniwersytet Gdański

e-mail: s.machowska@ug.edu.pl

\section{EMPIRYCZNA ANALIZA ZALEŻNOŚCI MIĘDZY OTWARTOŚCIĄ GOSPODARKI A WZROSTEM GOSPODARCZYM NA PRZYKLADZIE POLSKI} THE EMPIRICAL ANALYSIS OF DEPENDENCY BETWEEN OPENNESS OF ECONOMY VS. ECONOMIC GROWTH. CASE OF POLAND

DOI: $10.15611 /$ pn.2017.489.20

JEL Classification: F14, F15, F43

Streszczenie: Wzrost gospodarczy przejawia się przede wszystkim wzrostem PKB i PKB per capita. Wśród różnorodnych czynników wpływających na wielkość PKB jest handel zagraniczny. Stopień otwartości gospodarki odpowiednio determinuje wzrost gospodarczy, niemniej w literaturze toczy się dyskusja na temat tej zależności. Stąd w artykule postawiono dwa cele: wykazanie związku korelacyjnego między otwartością gospodarki a wzrostem gospodarczym oraz wykazanie wpływu otwierania się gospodarki na PKB per capita. Jako metodę badawczą przyjęto badanie korelacji między wspomnianymi zmiennymi oraz wnioskowanie na podstawie modelu regresji. Na podstawie przeprowadzonych badań można stwierdzić, że badanie korelacji między wzrostem gospodarczym a otwartością gospodarki wykazuje zależność dodatnią. Ponadto wzrost wskaźnika otwartości w okresie po przystąpieniu Polski do UE przekłada się na wzrost PKB per capita.

Słowa kluczowe: wzrost gospodarczy, wskaźnik otwartości gospodarki, badanie korelacji.

Summary: Economic growth is manifested primarily by the growth of GDP and GDP per capita. The foreign trade is one of various factors influencing the size of GDP. The degree of openness of the economy determines the economic growth. However, there is a debate in the literature on this dependency. Hence, the article sets out two goals: to show a correlative connection between the economy openness and the economic growth, and to present the influence of the economy openness on GDP per capita. The research method adopted is the correlation test based on the regression model. On the basis of the conducted research, it can be stated that the correlation test indicates a positive dependency. Moreover, the increase of the openness of the Polish economy after the accession to the EU results in the increase of GDP per capita.

Keywords: economic growth, economy openness factor, correlation test. 


\section{Wstęp}

Mechanizm i czynniki wzrostu gospodarczego są od wielu lat tematem zarówno prac teoretycznych, jak również badań empirycznych - ma to duże znaczenie ze względu na politykę gospodarczą oraz szeroko pojęty rozwój gospodarki. Wzrost gospodarczy oznacza dodatnie zmiany ilościowe w gospodarce i przejawia się wzrostem PKB i PKB per capita. Zatem jest on miernikiem oceny stanu gospodarki państwa - wyraża wartość wszystkich dóbr i usług wytworzonych w gospodarce w ciągu jednego roku pomniejszoną o wartość produktów potrzebnych na ich wytworzenie. Głównym makroekonomicznym celem gospodarowania jest maksymalizacja PKB w warunkach równowagi ekonomicznej, czyli możliwie szybki wzrost gospodarczy [Rymarczyk (red.) 2010, s. 243]. Wzrost gospodarczy jest postrzegany jako prawdopodobnie najważniejszy czynnik wpływający na dochody jednostek [Barro, Sala-i-Martin 2004, s. 6]. Z tego też względu PKB, a także jego determinanty interesują ekonomistów na całym świecie. W przypadku niniejszego opracowania badanym czynnikiem wpływającym na wzrost PKB jest handel zagraniczny.

Proces integracji krajów w ramach Unii Europejskiej związany jest ze wzajemnym otwieraniem gospodarek, co skutkuje intensyfikacją handlu między krajami. Jednocześnie handel zagraniczny to najstarszy i wciąż najważniejszy wymiar globalizacji gospodarczej. W polu zainteresowania badaczy leży zatem związek między otwartością gospodarki a wzrostem gospodarczym, bowiem stopień otwartości odpowiednio determinuje wzrost gospodarczy. Zjawisko otwierania się gospodarek nie jest zjawiskiem nowym, procesy, takie jak zmiany ustrojowe, integracja gospodarcza, globalizacja, kryzysy globalne, wpływają na stopień otwierania się krajów na wymianę handlową. Mimo że handel jest warunkiem koniecznym wzrostu i rozwoju, nie jest on oczywiście warunkiem wystarczającym. Handel przyczynia się do wzrostu gospodarczego i zmniejszenia ubóstwa zależnie od struktury gospodarki i pod warunkiem właściwej kolejności wprowadzania środków liberalizacji handlu oraz realizacji wzajemnie uzupełniających się strategii politycznych. Reformy krajowe mają podstawowe znaczenie dla utrzymania wzrostu, u którego podstaw leży m.in. handel z innymi krajami [Komisja Europejska 2012, s. 5].

Celem opracowania jest wykazanie związku korelacyjnego między otwartością gospodarki a wzrostem gospodarczym oraz wykazanie wpływu otwierania się gospodarki na wartość PKB per capita. Jako metodę badawczą przyjęto badanie korelacji między wspomnianymi zmiennymi oraz wnioskowanie na podstawie modelu regresji. Najprostszym wskaźnikiem opisującym otwartość gospodarki jest stosunek obrotów handlowych (eksportu i importu) do wartości produktu krajowego brutto. Nie jest to miara doskonała, ale na jej korzyść należy odnotować prostotę samego wskaźnika. Należy jednak ostrożnie podchodzić do wyciągania wniosków o otwartości danej gospodarki na podstawie wskaźnika otwartości, gdyż jego wysokość w dużym stopniu determinowana jest wielkością samej gospodarki. Im większa jest gospodarka, tym mniejszy jest omawiany wskaźnik. Na wartość tego wskaźnika wpływa również położenie geograficzne - jego wzrostowi sprzyjają: bliskie sąsiedztwo krajów 
o otwartych reżimach handlowych, skala obecności korporacji transnarodowych (handel wewnątrzkorporacyjny), skala reeksportu czy wreszcie tradycje historyczne i charakter polityki handlowej [Radło, Kowalewski 2008, s.10].

W literaturze przedmiotu podbudowa teoretyczna, dotycząca wpływu handlu zagranicznego na wzrost gospodarczy, jest niezwykle bogata. Koncepcja kosztów absolutnych A. Smitha czy teoria kosztów komparatywnych D. Ricardo to najpopularniejsze koncepcje odnoszące się do wpływu handlu zagranicznego na wzrost gospodarczy [Misztal 2010, s. 38]. Z nowszych ujęć teoretycznych należy wspomnieć o teorii luki technologicznej, zgodnie z którą poszczególne kraje charakteryzują się zróżnicowaniem pod względem poziomu zaawansowania wiedzy technicznej i tempa postępu technicznego. Kraje, które znajdują się na wyższym poziomie rozwoju, a tym samym - na wyższym etapie zaawansowania technologicznego, mogą za pomocą handlu zagranicznego przekazywać technologię innym partnerom [Topolewski 2014, s. 348]. Wśród nowych teorii handlu, a także teorii wzrostu endogenicznego odnaleźć można wiele przykładów związku handlu zagranicznego ze wzrostem gospodarczym (więcej na ten temat [Rynarzewski, Zielińska-Głębocka 2006]). Większość autorów przeprowadzonych badań empirycznych potwierdziła pozytywny związek między stopniem otwartości handlowej a wzrostem gospodarczym kraju w długim okresie. Jednym z częściej cytowanych opracowań na ten temat jest artykuł D. Dollara i A. Kraaya, w którym wykazali oni, że kraje charakteryzujące się wysoką otwartością handlową, mierzoną stosunkiem eksportu do PKB, charakteryzowały się wyższą dynamiką wzrostu gospodarczego od gospodarek mniej otwartych [Białowąs 2013, s. 18]. Jednak według Brodzickiego [2006, s. 3], mimo dominacji w literaturze przedmiotu wspomnianego poglądu, niektóre ujęcia teoretyczne i analizy empiryczne nie rozstrzygają jednoznacznie związku między otwartością gospodarki a wzrostem gospodarczym. Wspomniany autor twierdzi, że literatura empiryczna nie przynosi jednoznacznych dowodów na pozytywny wpływ otwartości gospodarki na wzrost gospodarczy. Również Pisarski [2013, s.103] sugeruje, że nie wszystkie analizy wpływu handlu zagranicznego na PKB potwierdzają pozytywny wpływ eksportu i importu na kształtowanie się PKB. Śliwiński [2011, s. 89] natomiast w swojej książce przytacza wybrane badania empiryczne nad rolą eksportu we wzroście gospodarczym. Na dziesięć podanych przykładów badań empirycznych trzy z nich nie przyniosły jednoznacznych wyników. Wydaje się więc, że kwestia ta nie doczekała się rozstrzygnięcia, na które zgadzaliby się wszyscy badacze.

\section{Przyjęta metodologia i metody badawcze}

W roku 2004 dziesięć krajów ${ }^{1}$, w tym Polska, przystąpiło do Unii Europejskiej, co stworzyło szansę na szybszy rozwój gospodarczy. Jednym z czynników powodu-

${ }^{1}$ W 2004 roku następujące kraje przystąpiły do UE: Cypr, Czechy, Estonia, Węgry, Litwa, Łotwa, Polska, Słowacja, Słowenia, Malta. 
jących wzrost gospodarczy w poszczególnych gospodarkach jest otwarcie nowych rynków na handel zagraniczny. Należy zaznaczyć, że gospodarka polska już przed akcesją charakteryzowała się wysoką dynamiką wzrostu gospodarczego oraz eksportu i importu. W procesie badawczym sformułowano następujące pytania badawcze:

1. Czy polska gospodarka charakteryzuje się pozytywną zależnością między wzrostem gospodarczym a otwartością gospodarki w badanym okresie 1993-2015?

2. Czy można wykazać, że otwieranie się gospodarki związane $\mathrm{z}$ akcesją Polski do UE wpłynęło na zmianę PKB per capita?

Zaznaczyć należy, że dobór danych przyjętych do analizy determinują dwa zasadnicze czynniki: po pierwsze moment wstąpienia Polski do Unii Europejskiej w 2004 roku, po drugie dostępność danych sprzed akcesji.

Sformułowano również dwie hipotezy badawcze:

1. Wzrost gospodarczy w Polsce mierzony PKB per capita jest dodatnio skorelowany z otwartością gospodarki mierzonej wskaźnikiem otwartości w okresie 1993-2015.

2. Wzrost otwartości gospodarki związany z akcesją Polski do Unii Europejskiej wpływa korzystnie na wzrost gospodarczy w badanym okresie, ceteris paribus.

W celu wykazania dodatniej zależności między PKB per capita a wskaźnikiem otwartości gospodarki dokonano badania korelacji na podstawie 23 obserwacji obejmujących lata 1993-2015. Natomiast w celu wyłonienia zmian w zakresie relacji PKB per capita i wskaźnika otwartości charakterystycznych dla okresu sprzed akcesji i okresu po przystąpieniu Polski do UE dokonano badania korelacji dla dwóch okresów, tj. 1993-2004 oraz 2004-2015.

Weryfikacja hipotez wymaga przeanalizowania danych empirycznych wyrażających wzrost gospodarczy mierzony wielkością PKB per capita, a także danych mierzących otwartość gospodarki. Zakres danych będących podstawą badań obejmuje zatem statystyki wzrostu gospodarczego mierzonego wskaźnikiem PKB per capita według parytetu siły nabywczej (current international dollar). Natomiast otwartość gospodarki mierzona jest wskaźnikiem otwartości (openness ratio) liczonym według wzoru:

$$
w 0=\frac{i m p o r t+e k s p o r t}{P K B},
$$

gdzie wo to wskaźnik otwartości.

Powyższy wskaźnik podawany jest w procentach. Wskaźnik otwartości wydaje się odpowiednim narzędziem do mierzenia otwartości gospodarki w przypadku poniższego badania. Jest on wprawdzie obarczony cechą, którą można nazwać wrażliwością na wielkość gospodarki (indeks przyjmuje wysokie wartości dla małych krajów i niskie dla dużych gospodarek ${ }^{2}$ ), o czym wcześniej wspomniano. Niemniej w przypadku badania jednego kraju nie ma to znaczenia.

\footnotetext{
${ }^{2}$ Wynika to z tego, że duże gospodarki zazwyczaj są bardziej samowystarczalne i niż małe.
} 
W celu weryfikacji hipotez dokonano badania korelacji i regresji liniowej między PKB per capita a wskaźnikiem otwartości. Do badania zależności zastosowano wykresy rozrzutu z linią regresji, obliczono m.in. współczynniki korelacji r-Pearsona dla poziomu istotności $p=0,05$. W każdym badanym przypadku sprawdzono i potwierdzono rozkład normalny reszt. Dane statystyczne użyte do badania pochodzą z zasobów Eurostatu oraz są wynikiem własnych obliczeń. Do badania korelacji i regresji posłużono się programem Statistica. Wzrost gospodarczy pełni rolę zmiennej zależnej, a otwartość gospodarki stanowi zmienną niezależną. Założono również hipotezę zerową wyrażającą się twierdzeniem, że między PKB per capita a wskaźnikiem otwartości zależność nie istnieje.

\section{Proces badawczy i wyniki badania}

Ogólny pogląd na zależność między wzrostem gospodarczym a otwartością gospodarki można uzyskać na podstawie badania korelacji. Na wykresie (rys. 1) przedstawiono zależność między PKB per capita a wskaźnikiem otwartości dla okresu 1993-2015. Korelację dodatnią między zmiennymi potwierdza rosnąca linia regresji. Współczynnik korelacji Pearsona wynosi 0,94, co świadczy o bardzo silnej zależności liniowej. Współczynnik determinacji $r^{2}$ równy jest 0,89 , co oznacza, że zmienność PKB per capita jest w 89\% wyjaśniona zmiennością wskaźnika otwartości gospodarki. Poziom istotności $p$ dla statystyki $t$ jest mniejszy od 0,05 , co wskazuje

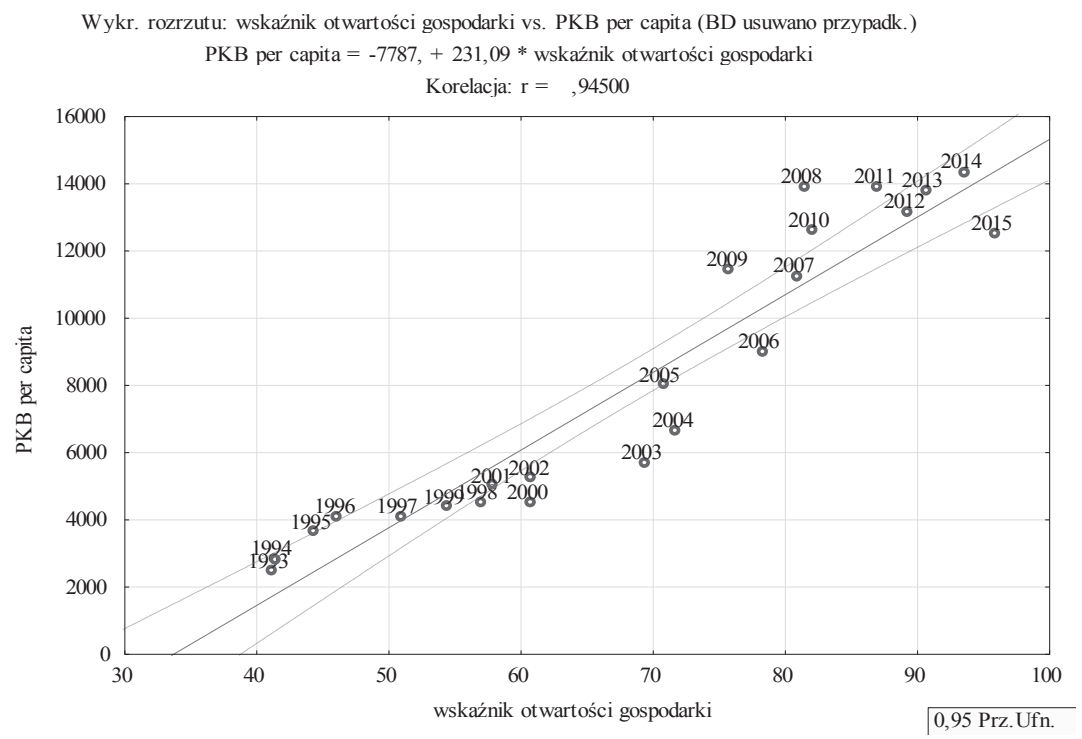

Rys. 1. Korelacja między PKB per capita a wskaźnikiem otwartości dla Polski w latach 1993-2015 Źródło: badania własne na podstawie danych Eurostatu. 
na to, że współczynnik korelacji jest istotnie różny od zera. Można zatem odrzucić hipotezę zerową mówiącą o tym, że badane zmienne nie mają ze sobą żadnego związku, współczynnik korelacji $r$ jest równy zero.

Na kolejnym wykresie (rys. 2) przedstawiono relację pomiędzy wzrostem gospodarczym wyrażonym jako PKB per capita a otwartością gospodarki mierzoną wskaźnikiem otwartości. Badanie dotyczy lat 1993-2004, czyli okresu sprzed akcesji Polski do Unii Europejskiej.

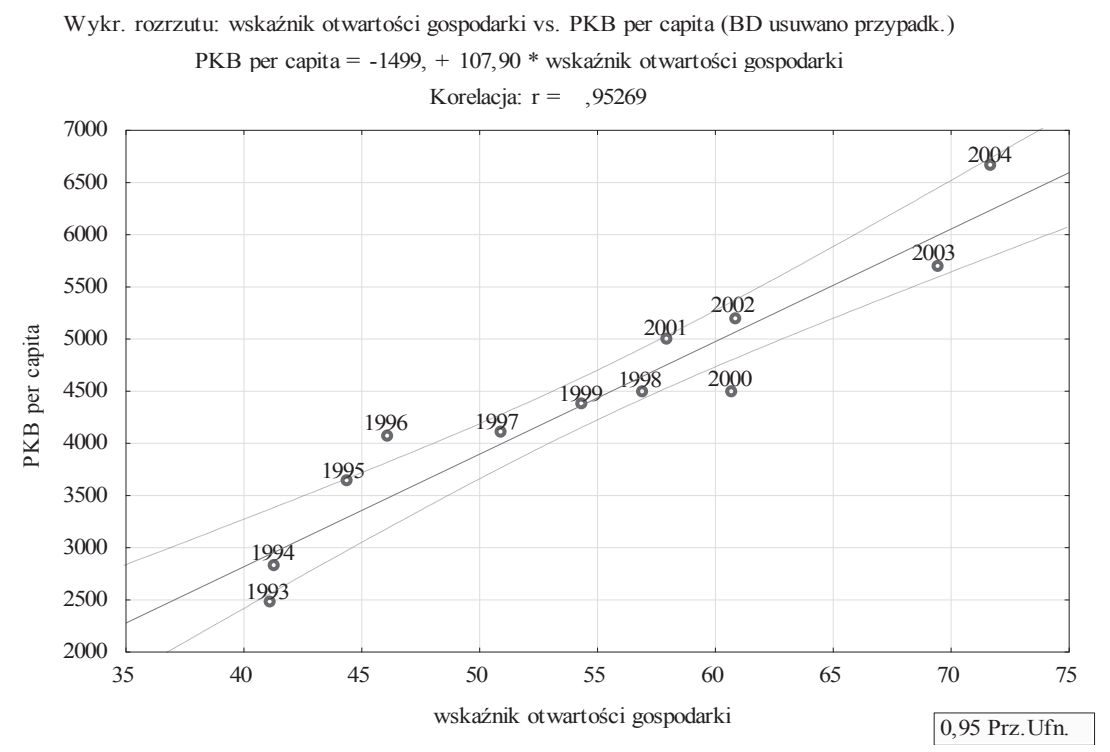

Rys. 2. Korelacja między PKB per capita a wskaźnikiem otwartości dla Polski w latach 1993-2004 Źródło: badania własne na podstawie danych Eurostatu.

Z badania korelacji wynika, że współczynnik korelacji r-Pearsona kształtuje się na poziomie $r=0,95$ przy założonym poziomie istotności $p=0,05$. Wynika z tego, że współczynnik korelacji jest istotnie różny od zera, a siłę tego związku według klasyfikacji J. Guilforda można określić jako „bardzo silną”. Na podstawie współczynnika regresji liniowej można stwierdzić, że zmiana wskaźnika otwartości o 10\% wywołuje zmianę PKB per capita o 107,90 jednostek pieniężnych (current international dollar). Współczynnik determinacji wynosi 0,91, co oznacza, że zmienność PKB per capita jest w 91\% wyjaśniona zmiennością wskaźnika otwartości. Powyższe badanie daje bardzo ogólny obraz korelacji między zmiennymi, niemniej potwierdza pogląd o dodatnim wpływie otwartości gospodarki na wzrost gospodarczy w badanym okresie.

Siła związku między wzrostem PKB a otwartością gospodarki zmienia się w czasie, nie można zatem założyć a priori, że każde badanie korelacji wykaże pozytywną zależność między badanymi zmiennymi. Dlatego na rysunku 3 przedstawiono 
korelację wymienionych wyżej parametrów charakteryzujących gospodarkę Polski w okresie od 2004 do 2015 r., a więc po przystąpieniu Polski do UE.

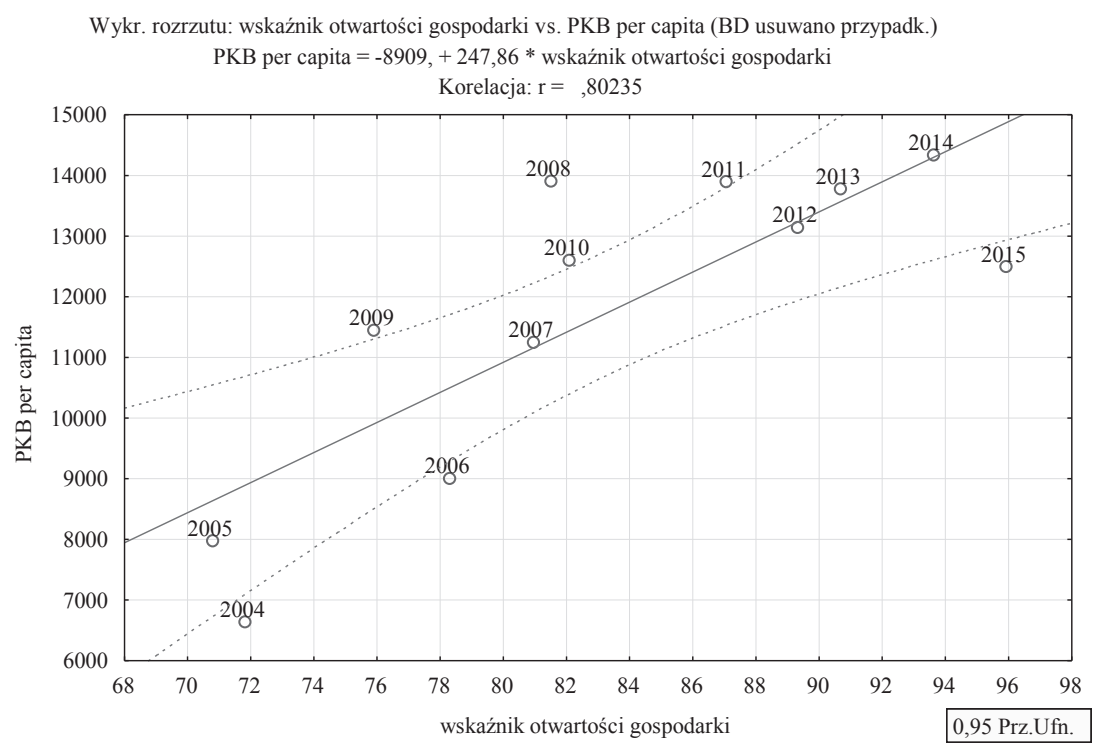

Rys. 3. Korelacja między PKB per capita a wskaźnikiem otwartości dla Polski w latach 2004-2015 Źródło: badania własne na podstawie danych z Eurostatu.

Po wyznaczeniu prostej metodą najmniejszych kwadratów można zauważyć, że korelacja między zmiennymi jest dodatnia. Współczynnik korelacji Pearsona dla badanej zależności wynosi $r=0,80$, przy poziomie istotności równym $p=0,05$. Z obliczeń wynika, że zależność między PKB a otwartością gospodarki mierzoną wskaźnikiem otwartości jest statystycznie istotna. Ocena siły tego związku za pomocą klasyfikacji J. Guilforda wskazuje na korelację „,bardzo silna”. Interpretując wskaźnik regresji liniowej, można stwierdzić, że wzrost wskaźnika otwartości o 10\% wywołuje wzrost PKB per capita o 247, 86 jednostek pieniężnych (current international dollar).

\section{Wnioski z badania}

Wyniki zaprezentowane na wszystkich wykresach rozpraszają wątpliwości co do charakteru związku między wzrostem gospodarczym a otwartością gospodarki w przeprowadzonych badaniach. Korelacja tych dwóch zmiennych jest ewidentnie dodatnia. Siła korelacji mierzona współczynnikiem r-Pearsona wykazuje we wszystkich trzech przypadkach silną zależność liniową. Współczynnik korelacji r-Pearsona jest we wszystkich badanych okresach stosunkowo wysoki i statystycznie istotny. Wobec powyższego można przyjąć, że hipoteza pierwsza: wzrost gospodarczy 
w Polsce mierzony PKB per capita jest dodatnio skorelowany z otwartością gospodarki mierzonej wskaźnikiem otwartości w okresie 1993-2015, zweryfikowana została pozytywnie.

Porównując wyniki badania zilustrowanego na rysunkach 2 i 3, można stwierdzić, że wskaźnik otwartości po akcesji Polski do UE dość znacznie uległ zwiększeniu, a PKB per capita istotnie przyspieszyło tempo wzrostu. Ponadto współczynnik dla predyktora wskaźnika otwartości gospodarki w badaniu pierwszym, dotyczącym okresu sprzed akcesji (rys. 1) wynosi 107,9, a w badaniu drugim, obejmującym okres po akcesji (rys. 2), 247,86. Różnica między tymi wskaźnikami wynosi 139,96 i jest dodatnia, co jest niezwykle istotne z punktu widzenia zarówno powyższych badań, jak i całej gospodarki. Oznacza to, że w okresie po przystąpieniu Polski do UE dziesięcioprocentowy wzrost wskaźnika otwartości wywołuje wzrost o 139,96 jednostek pieniężnych (current international dollar) PKB per capita większy niż w porównywalnym okresie sprzed akcesji. Jest to ewidentna korzyść dla gospodarki polskiej spowodowana przystąpieniem oraz konsekwencjami akcesji Polski do Unii Europejskiej. Można zatem przyjąć, że hipoteza druga: wzrost otwartości gospodarki związany z akcesją Polski do Unii Europejskiej wpływa korzystnie na wzrost gospodarczy w badanym okresie, ceteris paribus, została zweryfikowana pozytywnie.

Zważywszy na to, że korelacja wskazuje siłę zależności między zmiennymi, można $\mathrm{z}$ całą pewnością stwierdzić, że w przedstawionych badaniach PKB per capita jest silnie skorelowany ze wskaźnikiem otwartości gospodarki. Natomiast regresja wskazująca na kształt zależności wykazuje zależność liniową między badanymi zmiennymi.

\section{Podsumowanie}

W świetle teorii zależność między handlem zagranicznym a wzrostem gospodarczym jest szeroko opisywana począwszy od koncepcji kosztów absolutnych A. Smitha i kosztów komparatywnych D. Ricardo przez współczesne teorie handlu zagranicznego. Weryfikacji twierdzeń zawartych w modelach i koncepcjach można i należy dokonywać w badaniach empirycznych. W niniejszym opracowaniu podjęto próbę empirycznego potwierdzenia poglądu o dodatniej korelacji między wzrostem gospodarczym a otwartością gospodarki oraz wykazania, że akcesja Polski do Unii Europejskiej jest korzystna dla polskiej gospodarki ze względu na rosnący PKB per capita powodowany otwieraniem się rynku krajowego na rynki zagraniczne.

Udana próba jednoznacznego potwierdzenia, że przystąpienie Polski do Unii Europejskiej przyniosło efekty w postaci zintensyfikowania zależności między wzrostem gospodarczym a otwartością gospodarki i przyczyniło do wzrostu PKB per capita, jest przesłanką do twierdzenia, że wymiana handlowa stymulowana polityką gospodarczą jest istotną determinantą wzrostu gospodarczego.

Warto uzupełnić, że poza faktem przystąpienia Polski do UE wysoki poziom otwartości gospodarki jest wynikiem wieloletniego procesu transformacji i liberalizacji zasad prowadzenia handlu zagranicznego. Można wnioskować, że handel zagraniczny 
stanowi istotny kanał oddziaływania na gospodarkę. Jak wykazują zaprezentowane badania, oddziaływanie to stymuluje wzrost gospodarczy w dłuższym okresie. Uzyskanych wyników analizy empirycznej nie należy jednak uogólniać poprzez sprowadzenie ich do twierdzenia, że zależność między otwartością gospodarki a wzrostem gospodarczym jest zawsze i w każdych warunkach dodatnia. Efekty badań mogą bowiem zależeć m.in. od przyjętej metodologii, struktury i liczności próby badawczej, a także od przyjętej miary otwartości. Dlatego zastosowanie uniwersalnych zaleceń w polityce gospodarczej, bez uwzględnienia lokalnych czy indywidualnych uwarunkowań oraz czynnika czasu, może mieć negatywne konsekwencje dla rozwoju gospodarczego.

Uzyskane wyniki analizowanej korelacji między PKB per capita a wskaźnikiem otwartości nie zamykają problematyki badań nad tą zależnością. Pożądane są dalsze badania z uwzględnieniem innej metodologii i odmiennej miary otwartości gospodarki od przyjętej w niniejszym opracowaniu. Ponadto postuluje się systematyczną weryfikację badanej relacji, co umożliwi potencjalną reakcję w zakresie polityki gospodarczej na niepokojące zmiany zachodzące w badanym obszarze.

\section{Literatura}

Barro R., Sala-i-Martin X., 2004, Economic Growth, MIT Press, Cambridge - Massachusetts - London. Białowąs T., 2013, Otwartość handlowa $i$ dywersyfikacja eksportu a wzrost gospodarczy w latach 1995-2011, Annales Universitatis Mariae Curie-Skłodowska. Sectio H. Oeconomia, t. 47, nr 2.

Brodzicki T., 2006, Otwartość a wzrost gospodarczy - wyniki dotychczasowych badań $i$ wnioski na przyszłość, Analizy i Opracowania KEIE UG, nr 2

Komisja Europejska, 2012, Handel, wzrost gospodarczy i rozwój. Dostosowanie polityki handlowej $i$ inwestycyjnej do sytuacji krajów najbardziej potrzebujących, Urząd Publikacji Unii Europejskiej, Luksemburg, http://trade.ec.europa.eu/doclib/docs/2012/january/tradoc_149017.PL.pdf. (20.05.2017).

Misztal P., 2010, Hipoteza wzrostu gospodarczego stymulowanego przez eksport. Doświadczenia Polski w okresie 1997-2009, [w:] Misala J. (red.), Teoria i polityka wzrostu gospodarczego - osiagnięcia i doświadczenia, CeDeWu.pl Wydawnictwo Fachowe, Warszawa.

Pisarski M., 2013, Badanie zależności pomiędzy handlem zagranicznym a PKB z wykorzystaniem modelu VAR oraz przyczynowości Grangera, Ekonometria Econometrics, 4(42).

Radło M.J., Kowalewski O., 2008, Wpływ globalizacji na polska gospodarke, Materiały i Studia, Zeszyt nr 230, Wydawnictwo Narodowy Bank Polski Departament Komunikacji Społecznej, Warszawa.

Rymarczyk J. (red.), 2010, Międzynarodowe stosunki gospodarcze, PWE, Warszawa.

Rynarzewski T., Zielińska-Głębocka A., 2006, Międzynarodowe Stosunki Gospodarcze, Teoria wymiany i polityki handlu międzynarodowego, Wydawnictwo Naukowe PWN, Warszawa.

Śliwiński P., 2011, Przepływy kapitalu międzynarodowego a wzrost gospodarczy w krajach Europy Środkowo-Wschodniej w latach 1994-2008, Wydawnictwo Uniwersytet Ekonomiczny w Poznaniu, Poznań.

Topolewski Ł., 2014, Wymiana handlowa a wzrost gospodarczy, Studia i Prace WNEiZ, nr 37, t. 2. 